\begin{tabular}{r|l|l|l}
$\begin{array}{c}\text { Case Reports in } \\
\text { Gastroenterology }\end{array}$ & $\begin{array}{l}\text { Case Rep Gastroenterol 2011;5:132-135 } \\
\text { DOl: 10.1159/000326959 }\end{array}$ & $\begin{array}{l}\text { Published online: } \\
\text { April 6, 2011 }\end{array}$ & $\begin{array}{l}\text { O 2011 S. Karger AG, Basel } \\
\text { ISSN 1662-0631 } \\
\text { www.karger.com/crg }\end{array}$ \\
\hline
\end{tabular}

This is an Open Access article licensed under the terms of the Creative Commons AttributionNonCommercial-NoDerivs 3.0 License (www.karger.com/OA-license), applicable to the online version of the article only. Distribution for non-commercial purposes only.

\title{
Radiofrequency Ablation Resulting in Left Lobe Hypertrophy and Improved Resectability
}

\author{
R.T. Jones ${ }^{\mathrm{a}} \quad$ J.J. French ${ }^{\mathrm{a}} \quad$ J. Scott ${ }^{\mathrm{b}}$ D.M. Manas ${ }^{\mathrm{a}}$ \\ R.M. Charnley \\ Departments of a Hepatobiliary Surgery and ${ }^{\mathrm{b}}$ Radiology, Freeman Hospital, \\ Newcastle upon Tyne, UK
}

\section{Key Words}

Radiofrequency ablation · Liver metastasis · Resectability

\begin{abstract}
Surgical resection for colorectal liver metastases may only be considered when an adequate functional residual volume can be preserved. Selective portal venous embolisation may be used to increase this volume, whilst chemotherapy and radiofrequency ablation (RFA) can be used to treat inoperable lesions. A 73-year-old man with liver metastasis proceeded to surgery, with the intention to perform a right hemi-hepatectomy. Unexpectedly at laparotomy, despite adequate pre-operative imaging, both the right and middle hepatic veins were involved. At that time extended right hemi-hepatectomy was contraindicated by insufficient residual volume and RFA was performed. Follow-up imaging revealed atrophy of the lesion. Significantly, there was also left lateral lobe hypertrophy sufficient to permit resection, which was performed without complication. Thrombosis of intra-hepatic portal veins is a recognised complication of RFA but here it appears to have been beneficial. The case highlights the need for regular review of unresectable hepatic disease by a liver surgeon and could suggest new modalities of portal embolisation.
\end{abstract}

\section{Introduction}

Surgical resection is the only proven curative treatment for colorectal liver metastases, resulting in overall 5 -year survival rates of around 37\% [1,2]. Contraindications to resection include patient factors (co-morbidities precluding resection due to an unacceptably high operative risk) and tumour factors (presence of extensive extra-hepatic disease, including wide-spread local recurrence and extensive para-aortic 


\begin{tabular}{r|l|l|l}
$\begin{array}{r}\text { Case Reports in } \\
\text { Gastruenterology }\end{array}$ & $\begin{array}{l}\text { Case Rep Gastroenterol 2011;5:132-135 } \\
\text { DOI: 10.1159/000326959 }\end{array}$ & $\begin{array}{l}\text { Published online: } \\
\text { April 6, 2011 }\end{array}$ & $\begin{array}{l}\text { O 2011 S. Karger AG, Basel } \\
\text { ISSN 1662-0631 } \\
\text { www.karger.com/crg }\end{array}$ \\
\hline
\end{tabular}

lymphadenopathy). For a resection to be considered, it must be technically possible to remove tumour completely while preserving an adequate functional residual liver volume.

In recent years, the numbers of patients with colorectal metastases that are considered for hepatic resection have increased. Improvements in surgical techniques with an observed reduction in morbidity and mortality following resection have enabled a more aggressive surgical approach. New systemic chemotherapeutic agents such as oxaliplatin and irinotecan, and biological agents such as bevacizumab and cetuximab are also available, which in addition to treating in-transit disease also have an effect on established hepatic disease. In a proportion of individuals such treatment results in down-sizing of this hepatic disease, thus enabling them to be considered for resection [3]. When an extended hepatic resection is needed to clear disease that would leave insufficient residual liver volume, selective portal vein embolisation can be employed, which aims to increase the predicted functional residual volume, thus enabling a curative extensive resection [4].

Radiofrequency ablation (RFA) is the passage of electrical current through tissues to generate heat and cause cell death. Since its development in the late 1990s it has been used in the management of primary and secondary liver tumours, including colorectal liver metastases. Currently, RFA may be indicated if resection is not possible and the characteristics of the hepatic disease are favourable. Studies have shown a survival benefit of RFA compared with no treatment, but resection continues to be the gold standard, being the only modality offering long-term survival $[2,5,6]$. RFA is also used in combination with liver resection to treat amenable lesions in the residual liver that would otherwise preclude resection [7].

We report a case of colorectal liver metastasis in whom RFA appears to have facilitated a curative hepatic resection.

\section{Case Report}

A 69-year-old man was diagnosed with rectal cancer. Colonoscopy and computed tomography (CT) revealed no evidence of metastatic disease. Following anterior resection, histology confirmed a pT3 N2 rectal adenocarcinoma. Post-operatively he received 6 months of adjuvant chemotherapy (fluorouracil [5-FU] and folinic acid).

The patient remained symptom-free during follow-up, but 4 years later an elevated carcinoemobryonic antigen measurement was recorded $(27 \mu \mathrm{g} / \mathrm{l}$, normal range $0-10)$. CT and magnetic resonance imaging (MRI) revealed a lesion involving segments V and VIII of the right lobe of the liver, involving the right hepatic vein and close to the middle hepatic vein. There was no evidence of local or extra-hepatic recurrence on colonoscopy or positron emission tomography (PET) scan.

He proceeded to surgery with intention to perform a right hepatectomy. Intra-operative ultrasound, however, revealed the tumour to involve both the right and middle hepatic veins. Tumour clearance would therefore have necessitated an extended right hepatectomy. As the hepatic parenchymal volume of the left lateral segment and the caudate lobe (the functional residual volume) was inadequate to permit an extended right hepatectomy, this procedure could not be performed. The lesion was therefore treated with RFA.

His post-operative recovery was uneventful. Two weeks after surgery a CT scan confirmed that the RFA therapy had resulted in a large area of destruction in the right lobe of the liver. Adjuvant chemotherapy was commenced. Were the disease to remain static, right portal vein embolisation was to be considered, aiming to facilitate left lateral segment hypertrophy and permit an extended right hepatectomy. 


\begin{tabular}{r|l|l|l} 
Case Reports in & $\begin{array}{l}\text { Case Rep Gastroenterol 2011;5:132-135 } \\
\text { DOl: 10.1159/000326959 }\end{array}$ & $\begin{array}{l}\text { Published online: } \\
\text { April 6, 2011 }\end{array}$ & $\begin{array}{l}\odot \text { 2011 S. Karger AG, Basel } \\
\text { ISSN 1662-0631 } \\
\text { www.karger.com/crg }\end{array}$ \\
\hline
\end{tabular}

Follow-up cross-sectional imaging showed a $3 \mathrm{~cm}$ tumour around the previous RFA scar with tumour in segments V and VIII, extending into segments VI and I. The tumour had occluded the right hepatic vein and encased the origin of the middle hepatic vein, with extension up to the inferior vena cava, but the left hepatic and portal veins were spared. Full staging (PET and CT) showed no evidence of extra-hepatic disease. MRI also showed marked right lobe atrophy and unexpectedly, left lateral lobe hypertrophy (fig. 1). This lobar hypertrophy provided sufficient functional residual volume to render the lesion resectable.

An extended right hemi-hepatectomy with excision of a cuff of inferior vena cava and a disc of diaphragm was carried out. Histology of the specimen revealed a completely excised metastatic adenocarcinoma consistent with colorectal origin. The patient made an uncomplicated recovery and returned to work 20 days after surgery. Five years following liver resection he is alive with several lung metastases which have responded to chemotherapy. His quality of life is excellent and at the age of 81 he is still running his own business.

\section{Discussion}

Despite adequate pre-operative imaging, intra-operative hepatic ultrasound assessment revealed this case of hepatic colorectal metastasis to be unresectable at that time. Extended right hepatectomy (right trisectionectomy), necessary to clear tumour involving the right and middle hepatic veins, would have left an inadequate functional residual volume. RFA was performed with the intention to ablate the tumour. Following recovery from surgery right portal vein embolisation was planned, with the intention to cause left lateral segment hepatic hypertrophy sufficient to permit resection. Follow-up cross-sectional imaging revealed surprising findings. In addition to tumour ablation, RFA seems to have caused right portal vein occlusion and consequent left lateral lobe hypertrophy. RFA alone appears to have inadvertently resulted in sufficient functional residual volume to permit an extended right hepatectomy.

Portal vein (and arterial) thrombosis are known complications of RFA. Lesions near major vessels may not be heated uniformly due to the 'heat sink' effect of the blood flow. To abolish this effect, inflow occlusion - the Pringle manoeuvre - may be performed during the procedure. Experimental models and clinical experience have shown that RFA near the portal vein with inflow occlusion can result in thermal injury to the portal vein, thrombosis and deterioration of liver function. This effect was usually associated with inflow occlusion and cirrhosis $[8,9]$.

In most cases, inadvertent thrombosis of intra-hepatic portal veins would be a detrimental occurrence with potential for clot propagation, hepatic impairment and portal hypertension. In this case, thrombosis allowed for subsequent resection with curative intent.

This case shows the scope of RFA in contributing to liver hypertrophy and also highlights the need for regular review by a liver surgeon in patients with liver tumours previously deemed unresectable. 


\begin{tabular}{r|l|l|l}
$\begin{array}{r}\text { Case Reports in } \\
\text { Gastruenterology }\end{array}$ & $\begin{array}{l}\text { Case Rep Gastroenterol 2011;5:132-135 } \\
\text { DOI: 10.1159/000326959 }\end{array}$ & $\begin{array}{l}\text { Published online: } \\
\text { April 6, 2011 }\end{array}$ & $\begin{array}{l}\text { @ 2011 S. Karger AG, Basel } \\
\text { ISSN 1662-0631 } \\
\text { www.karger.com/crg }\end{array}$ \\
\hline
\end{tabular}

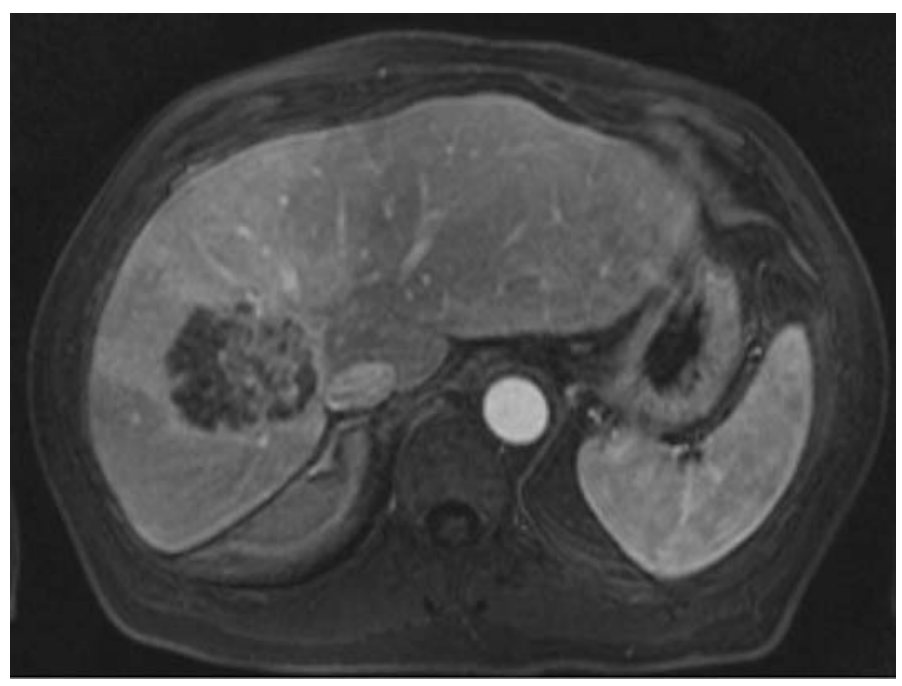

Fig. 1. MRI scan after RFA. The tumour involves the vena cava and middle hepatic veins. The right hepatic vein is not seen. The right lobe of the liver shows atrophy and the left lateral lobe hypertrophy.

\section{References}

1 Rees M, Tekkis PP, Welsh FK, O’Rourke T, John TG: Evaluation of long-term survival after hepatic resection for metastatic colorectal cancer: a multifactorial model of 929 patients. Ann Surg 2008;247:125-135.

$\$ 2$ Fong Y, Fortner J, Sun RL, Brennan MF, Blumgart LH: Clinical score for predicting recurrence after hepatic resection for metastatic colorectal cancer: analysis of 1,001 consecutive cases. Ann Surg 1999;230:309-318.

3 Bismuth H, Adam R, Lévi F, Farabos C, Waechter F, Castaing D, Majno P, Engerran L: Resection of nonresectable liver metastases from colorectal cancer after neo-adjuvant chemotherapy. Ann Surg 1996;224:509-520.

-4 Seymour K, Charnley RM, Rose J, Baudouin CJ, Manas DM: Extending the indications for curative liver resection by portal vein embolization. Br J Surg 2000;87:362-373.

-5 Abdalla EK, Vauthey JN, Ellis LM, Ellis V, Pollock R, Broglio KR, Hess K, Curley SA: Recurrence and outcomes following hepatic resection, radiofrequency ablation, and combined resection/ablation for colorectal liver metastases. Ann Surg 2004;239:818-825.

-6 Solbiati L, Livraghi T, Goldberg SN, Ierace T, Meloni F, Dellanoce M, Cova L, Halpern EF, Gazelle GS: Percutaneous radio-frequency ablation of hepatic metastases from colorectal cancer: long term results in 117 patients. Radiology 2001;221:159-166.

7 Elias D, Goéré D, Leroux G, Dromain C, Leboulleux S, de Baere T, Ducreux M, Baudin E: Combined liver surgery and RFA for patients with gastroenteropancreatic endocrine tumors presenting with more than 15 metastases to the liver. Eur J Surg Oncol 2009;35:1092-1097.

8 Lu DS, Raman SS, Vodopich DJ, Wang M, Sayre J, Lassman C: Effect of vessel size on creation of hepatic radiofrequency lesions in pigs: assessment of the 'heat sink' effect. AJR Am J Roentgenol 2002;178:47-51.

-9 de Baère T, Risse O, Kuoch V, Dromain C, Sengel C, Smayra T, Gamal El Din M, Letoublon C, Elias D: Adverse events during radiofrequency treatment of 582 hepatic tumors. AJR Am J Roentgenol 2003;181: 695-700. 